\title{
THE INTERACTION BETWEEN d-TUBOCURARINE AND GALLAMINE DURING HALOTHANE ANAESTHESIA*
}

\author{
M. M. GHONETM, M.B., B.CH., F.F.A.R.C.S. $\nmid$, R. B. URGENA, M.D. $\dagger$, \\ KENNETH DRETCHEN, M.S. $\$$, AND J. P. LONG, PH,D. $f$
}

\begin{abstract}
SINCE THE INTRODUCTION of d-tubocurarine (tubocurarine) and gallamine triethiodide (Flaxedil ${ }^{9}$ ) it has been assumed that both drugs act at the same site at the myoneural junction in a non-depolarizing fashion. Riker and Wescoe in 1951, ${ }^{1}$ studying one point on the dose response curves of both d-tubocurarine and gallamine, concluded that the two drugs were additive. Using the isometric responses of the tibialis anterior muscle of the cat to indirect stimulation, they demonstrated that the effect of two consecutive doses of either gallamine or d-tubocurarine was similar to the effect obtained when the two drugs were mixed. Wong in $19699^{2}$ studied the same interaction using the $\mathrm{LD}_{\mathrm{in} 0}$ in mice, the rabbit head-drop preparation and the rabbit sciatic-gastrocnemius muscle preparation. He concluded that the combined use of these two drugs produced "effects greater than that which would be expected if equivalent amounts of each drug were used alone." However, he too evaluated only one point on the dose response curves when studying the muscle preparation. Because of this, and because there is a marked species variation in the action of drugs at the myoneural junction, we undertook a study of this interaction in man.
\end{abstract}

\section{METHODS}

Fifty-two patients of both sexes, divided into three groups were studied. The first group consisting of 15 patients received d-tubocurarine. The second consisting of 17 patients received gallamine. The third consisting of 20 patients received a mixture of both drugs. Originally in the design of the study 20 patients were contemplated for each of the three groups but some cases had to be excluded because of variations of their blood gas values beyond normal limits. The age and sex distribution are shown in Figure 1. The distribution of body surface area as estimated from height and weight using the Dubois nomogram is shown in Figure 2. All were healthy within Class 1 and 2 of the ASA physical status classification and not receiving any drug known to influence the action of myoneural blocking agents. All were scheduled for ear or eye operations of at least three hours duration entailing minimal blood loss and requiring no profound muscle relaxation. The type and distribution of the operative procedures is shown in Table I. Pre-anaesthetic medication consisted mainly of morphine sulfate 5-12

-Supported in part by the Department of Anaesthesia Trust Fund and by usprs grants Nos. NS1396, NS4431 and usprs training grant 5 TO1 GM00141-11.

†Department of Anaesthesia, College of Medicine, University of Iowa, Lowa City, Iowa 52240.

tDepartment of Pharmacology, College of Medicine, University of lowa, Iowa City, Iowa 52240 .

66

Canad. Anaesth, Soc. J, vol. 19, no. 1, January 1972 


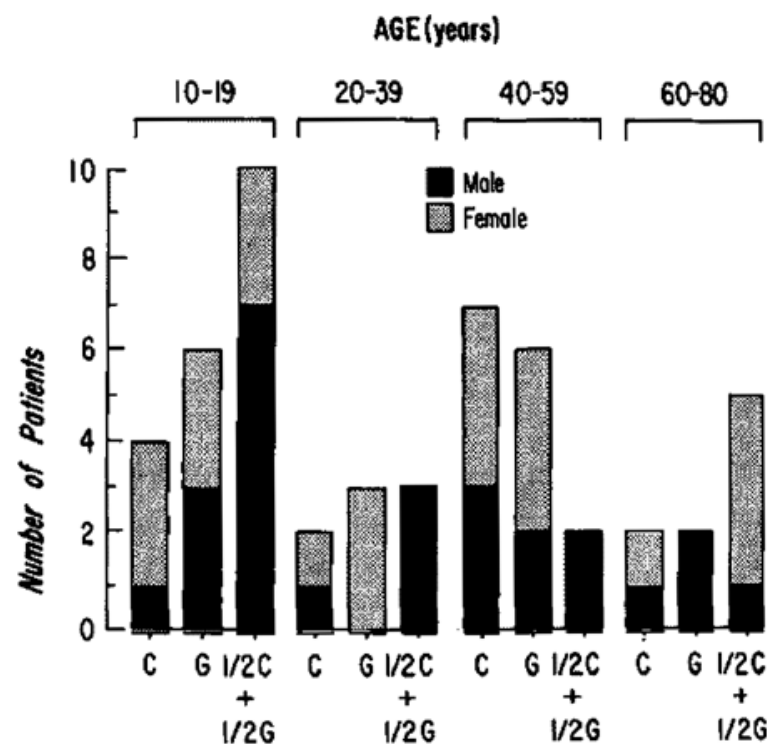

Figure 1. Age and sex distribution of patients. $\square$ dark areas, represents males; $\square$ light areas, represents females.

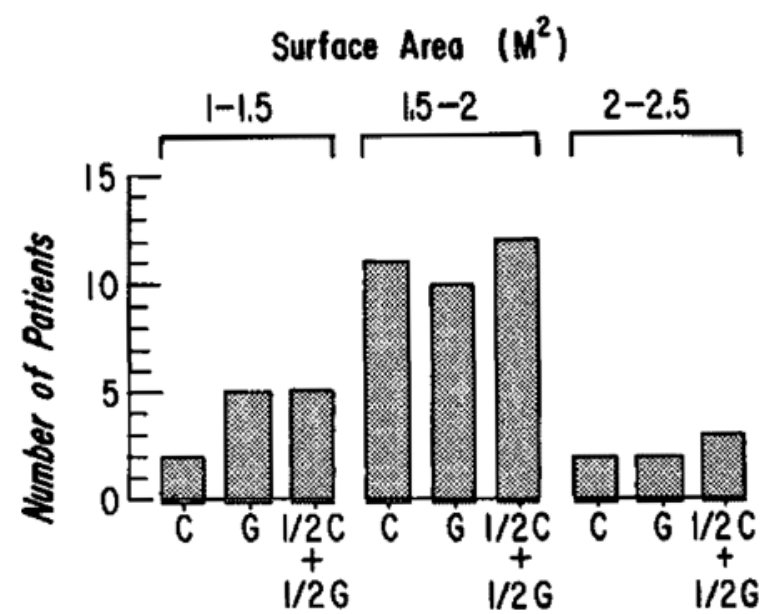

Figure 2. Distribution of surface area of patients.

$\mathrm{mg}$ and scopolamine $0.3-0.4 \mathrm{mg}$. Three patients received in addition $25 \mathrm{mg}$ of hydroxyzine (Atarax, Vistaril ${ }^{\$}$ ). Sixteen patients received pentobarbital 50-100 $\mathrm{mg}$. The drugs were injected intramuscularly one hour before operation. Induction of anaesthesia was achieved with thiopentone $100-250 \mathrm{mg}$ or nitrous oxide, oxygen and halothane. In some patients, a small dose of succinylcholine $30-40$ 
TABLE I

Distribution of Operative Procedures

\begin{tabular}{lcccc}
\hline & \multicolumn{4}{c}{ Number done with: } \\
\cline { 2 - 5 } \multicolumn{1}{c}{ Operative procedures } & d-tubocurarine & gallamine & $\begin{array}{c}\text { 1/2 d-tubocurarine } \\
\text { and 1/2 gallamine }\end{array}$ \\
\hline Scleral buckling & 6 & 7 & 9 \\
Mastoidectomy & 6 & 6 & 5 \\
Atticotomy & 2 & 1 & 2 \\
Mytingoplasty & 0 & 2 & 3 \\
Exploratory tympanotomy & 1 & 1 & 1 \\
and ossictloplasty & 1 & & \\
\hline
\end{tabular}

mg was given to facilitate endotracheal intubation. Anaesthesia was maintained with nitrous oxide, oxygen and halothane $0.5-1$ per cent administered to most patients using a non-rebreathing valve. Ventilation was either assisted or controlled. Arterial sampling was done for the measurement of oxygen and carbon dioxide tensions and $\mathrm{pH}$. Body temperature was monitored with a rectal thermistor probe and maintained close to $37^{\circ} \mathrm{C}$ by adjusting the temperature of the room. Five per cent dextrose in lactated Ringer's solution was given intravenously at approximately $10 \mathrm{ml} / \mathrm{Kg} / \mathrm{hr}$ for the first hour and then reduced to one quarter of that rate for the rest of the procedure.

The thumb of one hand was attached in full abduction to a Statham linear displacement force transducer. The other four fingers were splinted around the handle of the transducer. The ulnar nerve was stimulated at the wrist with subcutaneous needle electrodes; stimulus current was supplied by a Grass S4 stimulator with a Grass SIU5 stimulus isolation unit. The stimulation parameters were: supramaximal voltage, duration of $0.4 \mathrm{msec}$ and frequency of 18 per minute. The evoked responses of the adductor muscles were recorded using a Sanborn recorder.

Following control readings of twitch tension, the first group of patients was given d-tubocurarine $2.5 \mathrm{mg} / \mathrm{m}^{2}$ body surface area, intravenously, then $3 \mathrm{mg} / \mathrm{m}^{2}$ after another hour. The second group was given gallamine $15 \mathrm{mg} / \mathrm{m}^{2}$, then 20 $\mathrm{mg} / \mathrm{m}^{2}$ after another hour. The third group was given a mixture of $1.25 \mathrm{mg} / \mathrm{m}^{2}$ of d-tubocurarine and $10 \mathrm{mg} / \mathrm{m}^{2}$ of gallamine. These doses were chosen after a period of trial and error to identify doses producing adequate responses for a dose-response curve.

To study the effect on muscle blood flow, six mongrel dogs were anaesthetized with $30 \mathrm{mg} / \mathrm{Kg}$ of pentobarbital sodium administered intravenously. The brachial artery and vein were cannulated for blood pressure monitoring and drug administration respectively. The sciatic nerve was ligated and a shielded electrode was placed on the peripheral portion of the nerve. The tendon of the anterior tibialis muscle was dissected free and the blood supply to the muscle isolated by the method of Brown. ${ }^{3}$ Constant perfusion of the muscle with blood from the carotid artery was attained by the use of a Sigmamotor pump after ligating the common iliac artery. Perfusion pressure was monitored by a Statham pressure transducer interposed by means of a $\mathrm{T}$-tube betwcen the pump and the muscle. With flow 


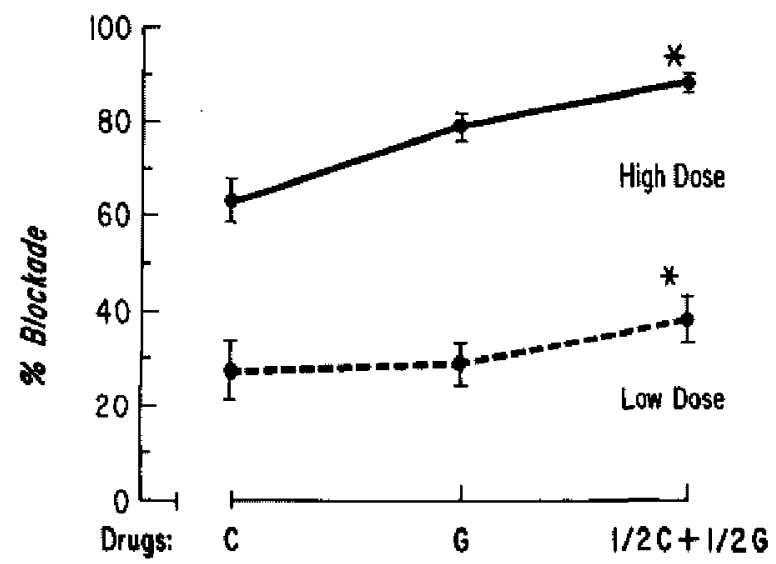

Figure 3. Dose-response curves for d-tubocurarine, gallamine and their combination in patients (arbitrary dose scale). $c$ represents d-tubocurarine. $c$ represents gallamine. Each point represents the mean of corresponding observations. Vertical bars indicate standard error. For dosage see the text. Points marked by are significantly different from the others.

remaining constant any change in pressure would reflect a change in vascular resistance. All animals were given heparin, $5 \mathrm{mg} / \mathrm{Kg}$, before the blood flow to the muscle was isolated. The stimulation parameters were supramaximal voltage of $10 \mathrm{v}$, pulse duration of $1 \mathrm{msec}$, applied at a frequency of 10 per minute. The contraction of the muscle was measured with a Grass force-displacement transducer and recorded on an Offner Dynograph recorder.

After stabilization of the muscle, d-tubocurarine $200 \mu \mathrm{g} / \mathrm{Kg}$, or gallamine 400 $\mu \mathrm{g} / \mathrm{Kg}$, or a combination of one half the dose of each was given intravenously to produce 40 to 60 per cent muscle blockade. Each animal received all three treatments with an interval between drug administration of 45 minutes after complete recovery from the previous treatment.

\section{Results}

The percent neuromuscular blockade in patients was analyzed as a $2 \times 3$ factorial analysis of variance. One factor was the 3 relaxants, the other was the high or low dose levels of each agonist (Figure 3 ). The results revealed a parallel shift between the high and low doses of the relaxants as well as parallel dose response curves.

If the two relaxants were additive rather than synergistic then the per cent blockade of the mixture should be equal to one half the per cent blockade of d-tubocurarine and one half the per cent blockade of gallamine at both the low and high dose. However when analyzed by the Student's $t$ test the blockade for the mixture was significantly greater than expected at both dose levels.

The degree of potentiation was calculated with the use of Figure 4. The dose response curve for d-tubocurarine intercepts the log dose axis at 0.336 , that for 


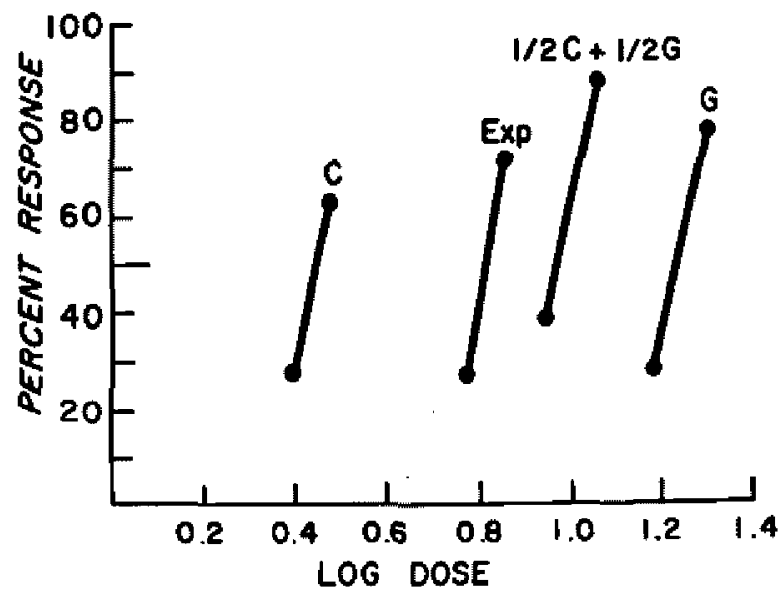

Ficure 4. Dose-response regression lines (Log-dose scale). $c$ represents d-tubocurarine. $\mathrm{G}$ represents gallamine. Exp. represents the expected line of $H c+y c$ if the mixture has a mere additive potency.

gallamine at 1.105 and that for the mixture at 0.848 . The expected curve for the mixture would have been at equal distance from those of d-tubocurarine and gallamine and should have crossed at 0.7205 .

If we assign a relative potency of 1 to d-tubocurarine, then the expected relative potency of the mixture to d-tubocurarine is antilog $(0.7205-0.336)$, or 2.421 . However, the observed relative potency of the mixture to d-tubocurarine is anti$\log (0.848-0.336)$, or 3.251 . The amount of synergism therefore is $3.251 / 2.421$ or 1.34 .

The difference in response between the low and high doses for the individual drugs did not match the magnitude of increase in dosage. For example, 15 $\mathrm{mg} / \mathrm{m}^{2}$ of gallamine produced 28 per cent blockade, while $20 \mathrm{mg} / \mathrm{m}^{2}$ increased the per cent blockade to 77 per cent. This was due to the cumulative effect of these drugs.

There was no statistical difference in the mean recovery times between the three agents in the way they were calculated as shown in Table II. The mean $\mathrm{PaCO}_{2}$ and $\mathrm{pH}$ for the d-tubocurarine group were $36.2 \pm 1.3$ torr and $7.44 \pm 0.00$ respectively, those for gallamine were $40.2 \pm 1.3$ torr and $7.45 \pm 0.01$, and those for the mixture were $39.8 \pm 1.1$ torr and $7.41 \pm 0.02$. The $\mathrm{PaO}_{2}$ for all patients was above 100 torr. Statistically the differences were not significant. The statistical method used for this and for the recovery times was analysis of variance, in a completely random design. The means were compared by Duncan's new

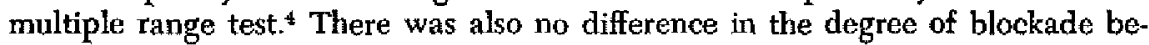
tween those patients who did and those who did not receive succinylcholine for endotracheal intubation and those who were intubated without relaxant. These results were analyzed by student's $t$ test. In all cases the level of probability was $p \leq 0.05$. 
TABLE II

Ëfects of d-Tubocurarine, Gallamine and their Mixture on Adductor Pollicis Muscle Contractions

\begin{tabular}{|c|c|c|c|}
\hline & Drug & $\begin{array}{l}\text { Per cent blockade } \pm \text { SE } \\
\text { of adductor pollicis } \\
\text { contractions }\end{array}$ & $\begin{array}{l}\text { Mean recovery } \\
\text { times* } \\
\text { (minutes } \pm \mathrm{SE} \text { ) }\end{array}$ \\
\hline Low dose & $\begin{array}{l}\text { d-tubocurarine } 2.5 \mathrm{mg} / \mathrm{m}^{2} \\
\text { gallamine } 15 \mathrm{mg} / \mathrm{m}^{2} \\
\text { d-tubocurarine } 1.25 \mathrm{mg} / \mathrm{m}^{2} \\
\text { gallamine } 7.5 \mathrm{mg} / \mathrm{m}^{2}\end{array}$ & $\begin{array}{l}27.47 \pm 6.41 \\
28.18 \pm 4.33 \\
39.00 \pm 5.06\end{array}$ & $\begin{array}{r}13.9 \pm 2.7 \\
14.8 \pm 2.9 \\
9.8 \pm 3.3\end{array}$ \\
\hline High dose & $\begin{array}{l}\mathrm{d} \text {-tubocurarine } 3 \mathrm{mg} / \mathrm{m}^{2} \\
\text { gallamine } 20 \mathrm{mg} / \mathrm{m}^{2} \\
\text { d-tubocurarine } 1,5 \mathrm{mg} / \mathrm{m}^{2} \\
\text { gallamine } 10 \mathrm{mg} / \mathrm{m}^{2}\end{array}$ & $\begin{array}{l}62.60 \pm 5.45 \\
77.88 \pm 3.61 \\
88.00 \pm 2.03\end{array}$ & $\begin{array}{l}42.4 \pm 1.3 \\
54.4 \pm 3.6 \\
42.3 \pm 4.1\end{array}$ \\
\hline
\end{tabular}

*For the low dosage, this was calculated for per cent blockade between $30-60$ per cent For the high dosage, it was calculated between $75-95$ per cent. The time was 80 per cent recovery. When this was not reached within the duration of the experiment, the time was given as 60 minutes.

TABLE III

Neuromuscular and Vascular Effiets of d-Tubocurarine, Gallamine and THEIR MIXTURE IN THE DOO

\begin{tabular}{|c|c|c|c|}
\hline & Gallamine & d-Tubocurarine & $\begin{array}{l}\text { 1/2 gallamine }+ \\
1 / 2 \text { d-tubocurarine }\end{array}$ \\
\hline $\begin{array}{l}\text { Per cent neuromuscular } \\
\text { blockade }\end{array}$ & $45 \pm 4.8^{\mathrm{a}}$ & $49 \pm 6.3^{b}$ & $93 \pm 4,0$ \\
\hline $\begin{array}{l}\text { Change in muscle perfusion } \\
\text { pressure (torr) }\end{array}$ & $0 \pm 0$ & $-10 \pm 1.3$ & $-9 \pm 0.8$ \\
\hline $\begin{array}{l}\text { Change in general blood } \\
\text { pressure (torr) }\end{array}$ & $+6 \pm 1.5$ & $-23 \pm 2.1$ & $-22 \pm 2.8$ \\
\hline
\end{tabular}

Values represent mean + sF, $n=6, p 0.05$

bMeans were compared by Duncan's New Multiple Range Test. Those means underlined by the sante line are not significantly different from each other; those means not underlined by the same line are significantly different from each other.

The results in the dogs show that when d-tubocurarine was given intravenously, decreases in blood pressure and perfusion pressure were produced simultaneously with the myoneural blockade. This probably was due to ganglionic blockade and release of histamine. Gallamine did not affect the vascular resistance and even caused slight increase in blood pressure. The d-tubocurarine effect on blood pressure and perfusion pressure was not altered by the concomitant administration of gallamine, while the myoneural blockade was potentiated (Table III).

\section{Discussion}

In the course of preparing this report we became aware that different individuals interpret and use the terms synergism, potentiation, and addition in different ways. To prevent misinterpretation, we are using the term synergism to describe the effects when two drugs given together produce a greater than 
algebraic sum of the effects which are produced by either drug administered alone. Addition describes the simple summation of the combined effects of two agents when given together. Potentiation is used as a synonym to synergism. Investigations into the nature of drug interactions require specific design. Without proper design experimental results cannot be evaluated properly or compared with results of other workers. ${ }^{5}$ Since gallamine and d-tubocurarine appear to act in an identical way at the myoneural junction, it is impossible to distinguish between synergistic and additive effects without taking into consideration the nature of the dose-response curves for these agents and the inherent variability in the response to the drugs. The latter phenomenon is well known and is manifested in both in vivo and in vitro preparations. To limit this variability our study was limited to fairly healthy patients undergoing operations which did not involve appreciable changes in haemodynamic or fluid balance and by calculating the dosage of the relaxant on the basis of body surface area rather than weight. It is apparent now that this method of dose calculation offers greater accuracy." We also demonstrated that the variability in the $\mathrm{Paco}_{2}$ and $\mathrm{pH}$ encountered and the occasional use of a small dose of succinylcholine for intubation of the trachea did not produce statistically significant effects. Since the dose-response curves were parallel, then one half of one dose of d-tubocurarine plus one half of a similar dose of gallamine should have yielded a result similar to the effect of the mean of the two drugs, if the interaction was additive. However, the combination yielded greater results, indicating synergism.

This effect could have resulted from an increase in drug concentration at the motor end plate due to an increase in regional blood flow to the muscle, caused by the drug mixture, or it could have been due to an effect at the receptors independent of the local perfusion. Slowing of the excretion or metabolism of one or both drugs cannot be included as a possible mechanism. At the dosage used, the initial effect and the recovery from paralysis is dependent solely on distribution to and away from the motor end plates. Monitoring of the muscle blood flow excludes the first possibility. This is also substantiated by the recovery times from d-tubocurarine, gallamine and the mixture, which were all the same. It is known that recovery from these agents is most dependent upon local tissue perfusion.

There is unanimous agreement that both d-tubocurarine and gallamine act in the same way at the myoneural junction. ${ }^{7}$ They cause the same graded reduction in end plate potential, which is reversed by anticholinesterases and they produce a poorly sustained contraction in response to indirect tetanic stimulation during partial block, followed by facilitation of twitch height. It is assumed that they combine with cholinergic receptors and thereby block the action of acetylcholine. The site of these receptors is open to some debate. While there is an overwhelming amount of data which demonstrate a blocking action at the post junctional site, there has been recently increasing emphasis on a presynaptic or prejunctional primary site of action. ${ }^{8}$ We are not aware of studies of the site of action of gallamine. Riker concluded from unpublished work that gallamine acts on mammalian motor nerve terminals like d-tubocurarine. There are those who speculate that the combined action of two drugs at the same site of primary action would not result in synergism, but might even take the form of compe- 
titive antagonism. ${ }^{10}$ In many situations, synergism is the result of two drugs acting on different receptors but producing the same response. However, one cannot be dogmatic when trying to apply the results of drug interaction studies to elucidate the sites of receptors. For the results to have more meaning in the receptor field, a preparation of the motor end plate as introduced by del Castillo and Katz would have been more appropriate. ${ }^{11}$ This would exclude the effects from other organs, and the stages of excitation-contraction coupling and contraction, leaving the depolarization of the membrane as the sole response.

From the clinical standpoint many anaesthesiologists mix d-tubocurarine and gallamine together ${ }^{12}$ or use one following the other, in the same patient. ${ }^{13}$ In this way, the differing cardiovascular effects of these drugs can be used to advantage. The results of our study suggest that one should be cautious when mixing these drugs, especially if intense myoneural blockade is not required.

\section{SUMMahy}

D-Tubocurarine, gallamine and a mixture of both drugs were each given to three separate groups of patients under halothane anaesthesia, to examine the interaction between the two non-depolarizing myoneural blocking agents. Mixing the two drugs resulted in synergism rather than simple addition. This affected the magnitude of blockade without altering its duration. Measurements in dogs ruled out the possibility that variation in muscle blood flow could be responsible for this synergism. That leaves the myoneural junction as the probable site of interaction.

\section{RÉSUMÉ}

Le d-tubocurarine, la gallamine et un mélange des deux ont chacun été donnés à trois groupes distincts de malades anesthésiés à l'halothane, pour examiner laction conjuguée de ces deux agents de bloc myoneural non dépolarisants. Le mélange des deux a résulté en un synergisme plutôt qu'en une simple addition. Ceci a affecté l'importance du bloc sans changer sa durée. Des mesures effectuées chez les chiens ont écarté la possibilité que le flot sanguin musculaire pourrait être responsable de ce synergisme. Ceci laisse la jonction myoneurale comme le site probable de linteraction.

\section{ACKNOWLEDGMENT}

The authors are indebted to $\mathrm{L}$. Burmeister for his generous assistance in statistical analysis of some of the data.

\section{REFERENCES}

1. Fiker, W. F. Ja \& Wescoe, W. C. The pharmacology of Flaxedil, with observations on certain analogs. Ann. New York Acad. Sc., 54: 373 (1951).

2. Wonc, K. C. Some synergistic effects of curare and gallamine., Fed. Proc. 28: 420 (1969)

3. Brown, G. L, The preparation of the tibialis anterior for close arterial injections., J. Physiol. $92: 220(1938)$

4. STrel, $\vec{R}$ \& Tonnie, J. H. Principles and procedures of statistics, lst edition New York: McGraw-Hill Book Co. (1960). 
5. Gephant, G. F., PlaA, G. L., \& Mrtcheic, C. L. The effects of ethanol alone and in combination with phenobarbital, chlorpromazine, or chlordiazepoxide., Toxicol. Appl. Pharmacol., 15: 405 (1969).

6. WaLts, L. F. Dillon, J. B. The response of newborns to succinylcholine and d-tubocurarine. Anesthesiology, 31 : 35 (1969).

7. Koenle, G. B. Neuromuscular blocking agents, The Pharmacological basis of therapeutics. 4th edition, edited by L. S. Goodman \& A. Gilman, New York: Macmillan, (1970).

8. REER, W. F. \& Oknuoto, M. Pharmacology of motor nerve terminals. Ann. Rev. Pharmacol., 9: 173 (1969).

9. Rrerer, W. F. Personal Communication.

10. Velostra, H, Synetgism and potentiation. Pharmacol. Revi, 8: 339 (1956).

11. Castmlo, J. del \& Katz, B. A study of curate action with an electrical micromethod. Proc. Roy. Soc., B 146: 339 (1957).

12. Hanswonth, A. M. \& BinghaM, W. An allergic circulatory collapse following the administration of muscle relaxants. Anaesthesia, 25: 105 (1970)

13. Foups, F. F. "Muscle relaxants" in 2/1966 volume of "Clinical Anesthesia" edited by J. F. Artusio, Philadelphia: F. A. Davis Co. 